\title{
Gender characteristics of interpersonal relations and aggression of adolescents in rural schools
}

\author{
Maria Vyshkvyrkina ${ }^{1, *}$ and Yulya Tushnova ${ }^{2}$ \\ ${ }^{1}$ Southern Federal University, Bolshaya Sadovaya Str., 105/42, Rostov-on-Don, 344006, Russia \\ ${ }^{2}$ Don State Technical University, Gagarin sq, 1, Rostov- on-Don, 344003, Russia
}

\begin{abstract}
The problem of aggressive behavior in adolescents is not new to psychological science. However, in a transitional society, it requires constant monitoring. At the same time, the rural school is of interest due to the relative isolation and limited number of subjects of interaction. The purpose of this study was to study the specifics of aggressive reactions and types of attitudes towards people in rural school adolescents of different sexes. The study involved students from rural schools, in the amount of 100 people aged $14-16$ years $(\mathrm{M}=15.3 ; \mathrm{SD}=1.2 ; 47 \%$ men $)$. The following methods were used: Bass-Darki questionnaire (adaptation by A.A. Khvan, Yu.A. Zaitsev, Yu.A. Kuznetsova.), Fundamental interpersonal Relations Orientation - Behavior (FIRO-B) (W. Schutz, adaptation by A.A. Rukavishnikov), as well as statistical methods (descriptive statistics, Mann Whitney U test). It was found that in the group of boys, physical aggression and resentment are more pronounced; girls are characterized by higher verbal aggression and feelings of guilt. Boys are also characterized by a high need for affection, and girls demonstrate a pronounced need for control over others. Prospects for the study consist in the subsequent analysis of the factors that determine the emergence of various aggressive and hostile reactions in adolescents, a comparison of rural and urban adolescents, as well as the characteristics of interpersonal relations in their relationship with the individual typological and gender characteristics of adolescents. The research results can be useful in organizing psychological support for adolescents in rural schools.
\end{abstract}

\section{Introduction}

The problem of aggressive behavior of teenagers and aggressive behavior at school today is significant not only for teachers, but also for a number of related specialists. Attention psychology addressed not only to the search of causality of aggressive behavior of teenagers and the facts of aggression in the school, but also to control aggressive behavior and mechanisms of its reduction in the school environment, relationships types of interpersonal relationships and aggression, gender differences of aggression are relevant at the moment.

In the literature, we find the concepts of aggression and aggressiveness, where the first is interpreted as purposeful destructive behavior that contradicts established norms and rules and harms the objects of attack [1], and the second as a personal characteristic acquired and

\footnotetext{
*Corresponding author: mavyshkvyrkina@sfedu.ru
} 
fixed in the process of development based on social learning [1]. At the same time, if aggressive behavior is initiated by a certain need, then aggressiveness will be a reaction to the stimuli recorded in the previous experience. Grebneva N.N., Slobodenyuk M.A., Variyasova E.V. it is noted that a number of studies (Loeber R. et al., 1993; Stattin H., Magnusson D., 1989) confirm that aggressiveness in the process of growing up can be transformed into a permanent behavior model [2]. This increases the practical significance of the problem of aggressive behavior in adolescence.

One of the reasons for the aggressive behavior of adolescents is the relationship of parents and aggressive behavior of parents towards third parties. A. Bandura's research (1973) showed a connection between children's aggression and aggressive parental attitudes. The connection between marital conflict and problems in adolescent behavior is investigated [35]. Walters G. D. and Espelage D. L. consider that hostility, anger and domination will mediate the connection between sibling aggression and school fights [6].

Equally-stuffy attitude of parents to acts of aggressive behavior of children and emotional closeness between parents and a child are also called as a predictor of the development of child aggression. O'Gara J. L. et al. studied Mexican American families and found that parental alienation by adolescents was an important predictor of crime [7]. Martin M. J. et al., Examining attachment behavior and hostility, showed that hostility is associated with conflict between mother and adolescent and externalization of problems, and disorders in attachment behavior in adolescents explain the relationship with internalizing problems [8]. El-Sheikh M. and Elmore-Staton L. concluded that secure attachment is a protective factor against behavioral problems associated with family conflict [4].

The article examines the influence of the model of aggressive behavior of parents on the consolidation of patterns of aggressive behavior of children, the relationship between father and son. Merrin G. J. et al. found that the hostility of the parents, the presence of the arrest of the father are associated with an increased risk of young people getting into gangs [9].

The article presents studies in which the mass media and popular culture are considered as a factor in the formation of aggressive behavior in children and adolescents. Martins N. et al., Studying the perception of teenage sitcoms, found that moral assessments are associated with sympathy for the aggressor, and not with the perception of the severity of the aggression [10]. van der Wal A. et al., describing the preferences of adolescents in relation to the types and contexts of television aggression, showed differences between boys and girls [11]. Zhang MX et al. discovered the regulatory role of gender in the relationship between friendship on adolescent social networks and physical, verbal and indirect aggression in China. Girls are more susceptible to the effects of physical aggression, but both boys and girls are more likely to choose verbally aggressive peers than indirectly aggressive ones [12]. Kuzmenko I. et al. revealed a greater need for management of impressions among students - users of social networks, while students who do not use social networks more express the need to establish close trusting relationships [13].

Considering the representation of the gender aspect in studies of aggression in adolescents, we can conclude that gender differences in aggressive behavior are presented in the study of various aspects, forms or predictors of aggression. It is necessary to point out a meta-study of gender differences in adolescent aggression [14-15]. Direct aggression, especially physical aggression, is more often manifested in boys, while pronounced differences in the manifestation of indirect aggression cannot be distinguished [14]. Sex differences in indirect aggression are always accompanied by a specific context and additional variables. Direct aggression is associated with problems of externalization, disturbed peer relationships and low levels of prosocial behavior, while indirect aggression is associated with problems of internalization and higher levels of prosocial behavior [15].

Gender differences in aggression indicate the importance of the problem of interpersonal relations in adolescents. In addition, communication plays an important role in the 
development of a teenager. Feldshtein D.I. notes that in the development of adolescents' relations, the phenomenon of mobilization is encountered - the creation of non-formal associations to satisfy the need for self-determination, shocking, challenge and demonstration of their relationship to the world [16]. At the same time, adolescent communities can take on a countercultural, asocial and antisocial orientation [16]. A number of studies note that in a transitional society, the situation is complicated by the chronic crisis context of socialization [17-19].

Pronina A. and Gerasimova E., exploring the connections between the types of aggression and interpersonal relations of adolescents in mono- and polyethnic classes, that the multiethnic composition of the micro-society reduces the manifestation of many forms of aggression among adolescents, increases the feeling of guilt and does not affect any types of interpersonal relationships mono- and polyethnic classes [20]. Attention is paid to the relationship between adolescent interpersonal relations skills and depressive symptoms, externalizing and internalizing behavior [21-22], suppression of emotions [23], connection with self-esteem and self-image of adolescents [24]. That is, the analysis of gender differences in adolescent aggression through the prism of types of attitudes towards people in a transitional society is valuable and will contribute to the enrichment of ideas about aggressive behavior of adolescents. Special interest arises in adolescents in rural schools, since this social space is relatively closed and has a limited number of subjects of interaction. The aim of the study was to study the specifics of aggressive reactions and types of attitudes towards people in rural school adolescents of different sexes.

\section{Materials and Methods}

The study involved 100 students from Secondary School No. 10, Khutor Krasnoe, Kushchevsky District, Krasnodar Territory, Russia, of which 53 were girls and 47 were boys, aged $14-16$ years $(M=15.3 ; S D=1,2)$. In accordance with the purpose of the study, the following methodological tools were used: "Questionnaire Bass-Darki (adaptation of A.A. Khvan, Yu.A. Zaitsev, Yu.A. Kuznetsov.)" [25], "Questionnaire of interpersonal relations (Fundamental interpersonal Relations Orientation - Behavior (FIRO-B)) (W. Schutz, adaptation by A.A. Rukavishnikov) "[26], statistical methods (descriptive statistics, Mann Whitney U test).

The assumptions were tested that: 1) the severity of aggressive and hostile reactions may differ in adolescents of different sex; 2) boys and girls may have different ways of treating people.

\section{Results}

The entire sample was divided by gender: boys (hereinafter -M) and girls (hereinafter -W). To test the assumption about the existence of differences in the severity of aggressive and hostile reactions in rural school students of different genders, a comparison was made between the Mann Whitney U test groups (Table 1).

Table 1. Aggressive and Hostile Reactions of Rural School Teens.

\begin{tabular}{|l|c|c|c|c|l|l|}
\hline \multirow{2}{*}{ Test scale / Group } & \multicolumn{2}{|c|}{$\begin{array}{c}\text { Group 1 (M) } \\
\mathbf{n = 4 7}\end{array}$} & \multicolumn{2}{c|}{$\begin{array}{c}\text { Group 2 (W) } \\
\mathbf{n}=\mathbf{5 3}\end{array}$} & \multirow{2}{*}{$\begin{array}{c}\text { Mann Whitney } \\
\text { U test }\end{array}$} & \multirow{2}{*}{ p } \\
\cline { 2 - 5 } & $\mathbf{M}$ & $\boldsymbol{\sigma}$ & $\mathbf{M}$ & $\boldsymbol{\sigma}$ & & \\
\hline Physical aggression & 6.78 & 1.79 & 4.37 & 1.92 & 463.000 & $0.000^{* *}$ \\
\hline Indirect aggression & 5.11 & 1.79 & 5.30 & 1.37 & 1184.000 & 0.667 \\
\hline Verbal aggression & 5.14 & 1.84 & 7.67 & 2.31 & 488.000 & $0.000^{* *}$ \\
\hline Negativism & 2.15 & 1.97 & 2.34 & 1.30 & 1135.000 & 0.433 \\
\hline
\end{tabular}




\begin{tabular}{|l|l|l|l|l|l|l|}
\hline Irritation & 5.45 & 2.37 & 5.55 & 2.21 & 1235.000 & 0.944 \\
\hline Suspicion & 7.17 & 1.97 & 7.36 & 1.83 & 1220.500 & 0.861 \\
\hline Resentment & 4.68 & 1.32 & 2.85 & 1.23 & 398.500 & $0.000^{* *}$ \\
\hline feelings of guilt & 4.23 & 1.29 & 5.79 & 1.25 & 497.500 & $0.000^{* *}$ \\
\hline
\end{tabular}

Footnote: **-significance level 0,01 .

As can be seen from the table, indicators of indirect aggression, irritation, negativism and suspicion in the groups of boys and girls are presented at the same level.

As a result of statistical data processing, differences in the severity of some aggressive and hostile reactions were established. Thus, boys have more pronounced physical aggression and resentment, while girls are characterized by higher verbal aggression and feelings of guilt.

The Mann Whitney $U$ test was also used to test the assumption about the differences between rural school boys and girls in dominant relationship types (Table 2).

Table 2. Orientation of relations between adolescents in rural schools.

\begin{tabular}{|l|c|c|c|c|l|l|}
\hline \multirow{2}{*}{ Test scale / Group } & \multicolumn{2}{|c|}{$\begin{array}{c}\text { Group 1 (M) } \\
\mathbf{n}=\mathbf{4 7}\end{array}$} & \multicolumn{2}{c|}{$\begin{array}{c}\text { Group 2 (W) } \\
\mathbf{n = 5 3}\end{array}$} & \multirow{2}{*}{$\begin{array}{c}\text { Mann Whitney } \\
\text { U test }\end{array}$} & \multirow{2}{*}{ p } \\
\cline { 2 - 5 } & $\mathbf{M}$ & $\boldsymbol{\sigma}$ & $\mathbf{M}$ & $\boldsymbol{\sigma}$ & & \\
\hline $\mathrm{Ie}$ & 4.66 & 1.40 & 4.38 & 1.81 & 1171.500 & 0.601 \\
\hline $\mathrm{Iw}$ & 4.87 & 1.57 & 4.87 & 1.64 & 1239.000 & 0.964 \\
\hline $\mathrm{Ce}$ & 6.51 & 1.35 & 7.04 & 1.14 & 968.000 & $0.047^{*}$ \\
\hline $\mathrm{CW}$ & 4.89 & 1.69 & 4.96 & 1.60 & 1222.500 & 0.872 \\
\hline $\mathrm{Ae}$ & 4.57 & 1.63 & 3.60 & 1.81 & 872.000 & $0.009^{* *}$ \\
\hline $\mathrm{Aw}$ & 3.45 & 1.56 & 2.64 & 1.69 & 857.500 & $0.006^{* *}$ \\
\hline
\end{tabular}

Footnote: ${ }^{* *}$ - significance level $0,01,{ }^{*}$ - significance level 0,05 ; I- inclusiveness, C-control, Aattachment, e- expressed behavior of the individual, w- wanted by the individual from others.

As shown in the table, in the group of boys, the need for inclusion, both expressed and required, the need for the required control and the need for the expression of affection and the required attachment are presented at a moderate level. The high level represents only the need for pronounced control. In the group of girls, similar results were obtained: the need for inclusion, the need for the required control and for expressed attachment are also presented at a moderate level. A high level of the need for pronounced control and a low level of the need for the required attachment was revealed.

Statistical processing in the expressed and required need for "inclusion" did not reveal any differences, as well as in the required need for control. However, it was found that boys have a more pronounced need for "attachment", both in expressed and required behavior. And girls have statistically higher pronounced behavior in the sphere of "control".

\section{Discussion}

The results of the study of the gender characteristics of interpersonal relations and aggression of adolescents in rural schools allow us to describe the prevailing types of aggressive and hostile reactions, as well as the types of attitudes in adolescent boys and girls.

In the severity of such aggressive and hostile reactions as "indirect aggression", "negativism", "irritation", "suspicion", gender characteristics were not revealed. However, it should be noted that both boys and girls showed a high level of suspicion, indicating caution and distrust of other people, as well as the tendency of adolescents to expect negative actions and actions from the surrounding people, to consider them enemies.

At the same time, differences were revealed in the severity of "physical aggression", "verbal aggression", "resentment" and "feelings of guilt". Boys have more pronounced "physical aggression" and "resentment". Girls are distinguished by high rates of "indirect 
aggression" and "feelings of guilt". Thus, boys' aggression is expressed in physical actions directed at others, and hostility is expressed in anger and hatred towards people, towards the world for unfulfilled desires, aspirations, dreams. Girls express their aggression through insulting others, in rude, obscene language, in reproaches and threats to the surrounding acquaintances and strangers.

Gender characteristics were also revealed in the prevailing attitudes of adolescents in rural schools. It has been proven that both boys and girls feel comfortable alone, but establishing and maintaining interpersonal contact is not difficult for them. At the same time, the respondents of both groups demonstrate social flexibility: they do not require control from others, but, if external control arises, they are tolerant of it.

Girls, in comparison with boys, are more prone to authoritarianism, manifested in the need to control others, make decisions for them, and take responsibility for themselves and others. Boys, in comparison with girls, show a higher level of need for affection. Boys themselves are ashamed of deep, emotional intimate relationships with others, with the manifestation of the entire spectrum of feelings, and demand from those around them to establish close, emotionally open relationships with them.

Similar results have been obtained in other studies. In particular, a number of authors [11, 14-15, 22, 27-29] come to the conclusion about the prevalence of physical aggression among male respondents and the dominance of verbal aggression among women. Studying the impact of television programming on adolescents, van der Wal A., Fikkers K.M., \& Valkenburg P.M. indicate that boys are more aggressive physically due to stereotypical perception of male gender roles, including on television, and compliance with this role increases the boy's self-esteem, leads to a positive self-attitude [11]. To be strong, to be able to stand up for yourself, your friends, the ability to fight back, to be a "tough guy" are the qualities that a boy should have. Verbal aggression is a distinctive quality of girls, because they are less developed physically, but have a higher verbal development. At the same time, society considers male physical aggression permissible, and does not accept the use of physical force by women. In the study, Khwan A.A. it was shown that rural adolescents have higher suspicion and physical aggression than urban adolescents [30]. It is also indicated that rural boys and girls exhibit similar types of aggressive behavior (physical aggression, guilt, suspicion).

In the studies of Russian scientists, the influence of various factors on the severity of certain aggressive reactions has been proven. So Razova O.E., Gudkova E.V. revealed the relationship of high physical aggression in boys with a high level of offensiveness, intransigence, and the prevailing verbal aggression of girls is associated with high sensitivity, vindictiveness and self-aggression [31]. Studying the relationship between gender aspects and aggressive behavior of adolescents, Grishina E.A., Kuznetsova S.O. and others describe the dynamics of the prevailing types of aggressive reactions in adolescents at different ages [32-33]. The authors point out that at the age of 9-11 years, boys show direct physical and direct verbal aggression, and girls - indirect verbal aggression. At the age of 12-13, with the growth of verbal and physical aggression, negativism also increases, by the age of 14-15, the severity of verbal aggression increases by $20 \%$. At the same time, Grishina E.A. believes that the factors influencing the development of aggressiveness in adolescents include the peculiarities of family upbringing, the attitude of parents and adults towards adolescents, emotional rejection and excessive control on the part of significant adults and hormonal explosion [32]. And Kuznetsova O.S. believes that the factors influencing the development of aggression in adolescence are sociometric status and self-esteem [33]. The author proved that adolescents with a high sociometric status also demonstrate a high level of physical or verbal aggression, and the level of self-esteem is directly related to the level of aggression, and the higher self-esteem becomes, the higher the level of various aggressive reactions is observed. 


\section{Conclusions}

The results of the study of the gender characteristics of interpersonal relations and aggression of adolescents in rural schools made it possible to formulate the following conclusions:

1. in the group of boys, physical aggression and resentment are expressed to a greater extent, in comparison with girls;

2. girls are characterized by higher verbal aggression and feelings of guilt, in comparison with boys;

3. Boys are distinguished by a high need for affection, expressed in the desire not only to share emotions and feelings themselves, to build intimate relationships with others, but also to demand a similar attitude towards themselves from others;

4. Girls demonstrate a pronounced need for control over others, they are distinguished by the desire to make decisions for themselves and for them, a tendency to take a leading role, the role of a leader.

Prospects for the study consist in the subsequent analysis of the factors that determine the emergence of various aggressive and hostile reactions in adolescents, as well as the peculiarities of interpersonal relations in their relationship with the individual typological and gender characteristics of adolescents.

\section{References}

1. S.N. Enikolopov, The Special Child: Research and Aid Experience 1, 18-26 (1998) https://www.studmed.ru/view/enikolopov-sn-agressivnoe-povedenie-u-detey-osobyyrebenok-issledovaniya-i-opyt-pomoschi-1998-vyp-1-s-18-26_37b908abc99.html

2. N.N. Grebneva, M.A. Slobodenyuk, E.V. Variyasova, Psychology and Law 4, 134-148 (2019) https://doi.org/10.17759/psylaw.2019090410

3. N. Zhou, C. Buehler, The Journal of Early Adolescence 39(1), 5-27 (2019) https://doi.org/10.1177/0272431617725193

4. M. El-Sheikh, L. Elmore-Staton, Development and Psychopathology 16(3), 631-648 (2004) https://doi.org/10.1017/S0954579404004705

5. C.M. Stocker, M.K. Richmond, S.M. Low, E.K. Alexander, N.M. Elias, Social Development 12(2), 149-161 (2003) https://doi.org/10.1111/1467-9507.00226

6. G.D. Walters, D.L. Espelage, Psychology of Violence 10(1), 48-57 (2020) https://doi.org/10.1037/vio0000227

7. J. L. O'Gara, E.J. Calzada, S.Y. Kim, American Journal of Orthopsychiatry 90(1), 7077 (2020) https://doi.org/10.1037/ort0000394

8. M.J. Martin, M.L. Sturge-Apple, P.T. Davies, G. Gutierrez, Journal of Family Psychology 33(5), 586-596 (2019) https://doi.org/10.1037/fam0000529

9. G.J. Merrin, J.P. Davis, K.M. Ingram, D.L. Espelage, American Journal of Orthopsychiatry 90(5), 623-632 (2020) https://doi.org/10.1037/ort0000491

10. N. Martins, M.L. Mares, M. Malacane, A. Peebles, Communication Research 47(8), 1181-1205(2020) https://doi.org/10.1177/0093650216644016

11. A. van der Wal, K.M. Fikkers, P.M. Valkenburg, Communication Research 47(8), 12061227 (2020) https://doi.org/10.1177/0093650219832231

12. M.X. Zhang, H.Y. Liu, Y.Y. Zhang, Frontiers in Psychology 11, 658 (2020) https://doi.org/10.3389/fpsyg.2020.00658 
13. I. Kuzmenko, Y. Mochalova, Y. Tushnova, A. Korochentsova, 10th international conference on education and new learning technologies. EDULEARN Proceedings, 2160-2164 (2018) https://doi.org/10.21125/edulearn.2018.0596

14. J. Archer, Review of General Psychology 8(4), 291-322 (2004) https://doi.org/10.1037/1089-2680.8.4.291

15. N.A. Card, B.D. Stucky, G.M. Sawalani, T.D. Little, Child Development 79(5), 1185 1229 (2008) https://doi.org/10.1111/j.1467-8624.2008.01184.x

16. D.I. Feldstein, National Psychological Journal 2, 6-11 (2010) https://cyberleninka.ru/article/n/izmenyayuschiysya-rebenok-v-izmenyayuschemsyamire-psihologo-pedagogicheskie-problemy-novoy-shkoly

17. S.Yu. Florovsky, Problems of modern education 6, 36-51 (2019) https://cyberleninka.ru/article/n/stil-mezhlichnostnogo-otnosheniya-isotsialnopsihologicheskaya-adaptirovannost-sovremennyh-podrostkov

18. E.P. Belinskaya, Psychological research 7(36), 3 http://psystudy.ru/index.php/num/2014v7n36/1014-belinskaya36.html

19. N.A. Zhuravleva, Psychological journal 27(1), 35-44 (2006)

20. A. Pronina, E. Gerasimova, International Journal of Instruction 11(4), 1-16 (2018) https://doi.org/10.12973/iji.2018.1141a

21. E.M. Rodriguez, G.R. Donenberg, E. Emerson, et al., Journal of youth and adolescence 44(4), 952-963 (2015) https://doi.org/10.1007 / s10964-015-0263-7

22. M.H. Bornstein, Chun-Shin Hahn, O.M. Haynes, Development and Psychopathology 22(4), 717-735 (2010) https://doi.org/10.1017/S0954579410000416

23. W. Tsai, D. Julie Nguyen, B. Weiss, Journal of Abnormal Child Psychology 45(4), 657669 (2017) https://doi.org/10.1007/s10802-016-0192-2

24. I.V. Arendachuk, Bulletin of the Saratov University. New series. Series Acmeology of Education. Developmental psychology 6(4), 356-360 (2017) https://doi.org/10.18500/2304-9790-2017-6-4-356-360

25. A.A. Khvan, Yu.A. Zaitsev, Yu.A. Kuznetsova, Psychological diagnostics 1, 35-38 (2008)

26. A.A. Rukavishnikov, Interpersonal relations questionnaire (SPC, Psychodiagnostics Yaroslavl, 1992)

27. S.M. Coyne, J. Archer, M. Eslea, T. Liechty, Aggressive Behavior 34, 577-583 (2008) https://doi.org/10.1002/ab.20266

28. K.N. Graves, Aggression and Violent Behavior 12, 131-140 (2007) https://doi.org/10.1016/j.avb.2004.08.002

29. J.R. Linder, K.A. Lyle, American Journal of Media Psychology 4, 24-42 (2011) http://digitalcommons.linfield.edu/psycfac_pubs/8

30. A.A. Khvan, Bulletin of the Nizhny Novgorod University. N.I. Lobachevsky. Series: Social Sciences 2(38), 182-189 (2015) https://cyberleninka.ru/article/n/osobennostilichnosti-gorodskih-i-selskih-podrostkov-v-kontekste-psihologicheskogo-zdorovya

31. E. Gudkova, O. Razova Universum: Psychology and Education 4(58), (2019) https://7universum.com/ru/psy/archive/item/7141

32. E.A. Grishina, Modern education 2, 84-94 (2016) https://doi.org/10.7256/24098736.2016.2.17344. 
33. S.O. Kuznetsova, Bulletin of Slavic Cultures 4 (2010) https://cyberleninka.ru/article/n/psihologicheskie-osobennosti-agressivnosti-vpodrostkovom-vozraste 